Review

\title{
On the Way to Improve the Environmental Benignity of Chemical Processes: Novel Catalysts for a Polymerization Process
}

\author{
Silvana F. Rach and Fritz E. Kühn * \\ Molecular Catalysis, Catalysis Research Center der Technischen Universität München, \\ Lichtenbergstrasse 4, D-85747 Garching, Germany \\ * Author to whom correspondence should be addressed; E-mail: fritz.kuehn@ch.tum.de; \\ Fax: +49- (0)89-289-13473
}

Received: 10 February 2009 / Accepted: 14 March 2009 / Published: 19 March 2009

\begin{abstract}
An example for a process that can, in principle, be improved by the application of a catalyst is the synthesis of poly(2-methyl-propene)s ("polyisobutenes"), which are important for numerous industrial applications. Each year several 100,000 t are produced. The production of low-molecular weight polyisobutenes by means of cationic initiation by an excess of Lewis acids is well established. Typically, these initiators require the usage of solvents like chloroform, dichloromethane and ethylene and temperatures far below $0{ }^{\circ} \mathrm{C}$ $\left(-100{ }^{\circ} \mathrm{C}\right.$ in the case of ethylene as solvent). Solvent stabilized transition metal complexes with weakly coordinating counter anions overcome these drawbacks and thus are not only more efficient, but also more environmentally benign: they can be applied at ambient temperature and in non chlorinated solvents at low concentrations.
\end{abstract}

Keywords: Solvent ligands, weakly coordinating anions, transition metals, polymerization.

\section{Introduction}

Commercially available polyisobutenes (PIBs) have, depending on their molecular weight and characteristic properties, various industrial applications. According to this, they can be divided into three large groups of high-, medium- and low-molecular weight polyisobutenes. The rubber-like highmolecular weight polyisobutenes $\left(\mathrm{M}_{\mathrm{n}}>300 \mathrm{~kg} \cdot \mathrm{mol}^{-1}\right)$ are used as chewing gum base as well as in noncrosslinked rubber goods. The medium-molecular weight polyisobutenes with molecular weights 
between 40 and $120 \mathrm{~kg} \cdot \mathrm{mol}^{-1}$, which are highly viscous liquids, are mainly applied as glues and for sealants. The colourless, honey-like low-molecular weight polyisobutenes have molecular weights between 0.3 and $3 \mathrm{~kg} \cdot \mathrm{mol}^{-1}$. This is, with a 750,000 t/a production worldwide, by far the most important industrial class of isobutene polymers and is comprised of the so-called conventional lowmolecular weight PIBs that usually contain less than $10 \%$ terminal (exo) $\mathrm{C}-\mathrm{C}$ double bonds and the highly reactive polyisobutenes which contain more than $60 \%$ terminal $\mathrm{C}=\mathrm{C}$ bonds (see Scheme 1) $[1,2,3]$.

Scheme 1. General scheme for the polymerization of isobutene.
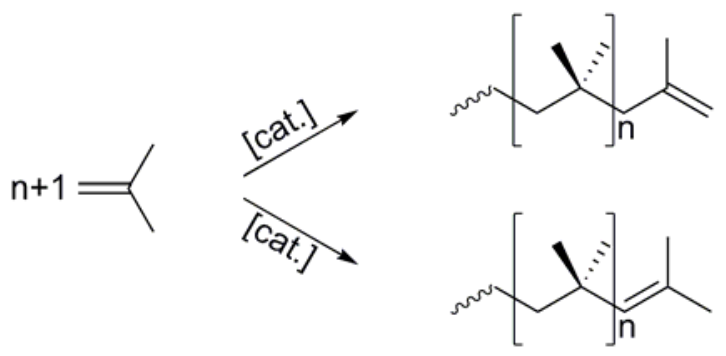

(exo)

(endo)

The additives for lubricants, gasoline and diesel fuel sectors make up the largest end-use market for low-molecular weight PIBs (that preferably have a high content of terminal vinyl groups). For example almost all dispersant products are based on functionalized PIB polymers, e.g. their succinic anhydrides and succinimides and other chemical derivatives. The presence of these dispersants in engine oils (up to 10 weight percent) helps to avoid agglomerations, coagulations and precipitations of insoluble substances and to reduce friction, as well as corrosion. When used as gasoline and diesel additives, they keep the injection system clean. In addition to their use as intermediates for lubricating additives, polyisobutene derivatives can also be used as lubricants by themselves or as components of formulated lubricant packages. There, they act as thickening/lubricating agents, control deposits as well as exhaust system blocking, reduce exhaust smoke and enhance anti-scuffing protection.

Due to these additives, oil change intervals for passenger cars and trucks are longer and accordingly, the need for engine oils diminishes and cars and trucks can operate more fuel-efficiently. As the need for the reduction of exhaust gases and fine dust particles increases and as the requirements as well as the demand for eco-friendly (polyisobutenes are extraordinarily resistant against chemicals and are considered to have no chronic hazard associated with exposure under normal industrial use) additives grow very fast, the development of more efficient additives with improved performance, gains in importance daily [4-9].

As highly reactive polyisobutenes and their derivatives in general are considered to be the most suitable substances for these applications, their production increases as well as the search for even better production methods and higher quality products. Due to the fact that mainly terminal $\mathrm{C}=\mathrm{C}$ double bonds are accessible for functionalizations (normally, these bonds are distributed all over the chain), generating polymers with a high unsaturated end group content is an important task for scientists working on this field of research. Additionally, much work is being and has to be done to produce highly reactive polyisobutenes in a more environmentally benign and cost-efficient way. 


\section{Industrial Production of Highly Reactive PIBs}

In 1873, the first triisobutene was synthesized via the reaction of isobutene with "weak" sulphuric acid [10]. More than 50 years later, it was observed that heated silicate can initiate the polymerization of isobutene, yielding mixtures of low molecular weight polymers [11,12].

The breakthrough came only a few years later with a process that still runs almost unchanged since it was first commercialised in 1938 by IG Farben in Ludwigshafen, Germany [13,14]. So far, enterprises all over the world mainly produce polyisobutenes by means of initiation by protonic and Lewis acids, such as $\mathrm{AlCl}_{3}, \mathrm{BCl}_{3}$ and $\mathrm{BF}_{3}$ and a proton source, e.g. traces of contaminations like water, hydrochlorides or hydrofluorides as co-initiator $[1,15,16]$. Typical solvents are methyl chloride, dichloromethane and ethylene. As the reaction is slightly exothermic and the solvents have low boiling points (ethylene: $\mathrm{bp}=-103.7^{\circ} \mathrm{C}$ ), temperatures of $-10{ }^{\circ} \mathrm{C}$ or below $\left(-100{ }^{\circ} \mathrm{C}\right.$ in the case of ethylene) are required to keep the reaction under control and to adjust to the desired molecular masses (in accordance with the Arrhenius equation (equation 1), the molecular weight increases with decreasing polymerization temperature) $[1,3,8,9,16-19]$. The energy consumption of this process is accordingly immense:

$$
\ln \mathrm{M}_{\mathrm{n}} \sim 1 / \mathrm{T}
$$

Although it is well known that the chain length of the polymers is inversely proportional to the reaction temperature, the majority of all industrially produced low-molecular weight polyisobutenes are manufactured by the conventional cationic polymerization, via initiation by an excess of Lewis acids like aluminium alkyl chloride or aluminium(III) chloride. Besides considerable energy consumption for cooling $\left(-20{ }^{\circ} \mathrm{C}\right.$ for the production of highly reactive polyisobutene with $\mathrm{AlCl}_{3}$ as initiator), this process leads to large quantities of chlorine containing solid waste, plus thousands of tons of chlorine containing wastewater [7].

A further drawback of this method is the fact that catalysis with halogen-containing Lewis acids results in the addition of halogens to the polymer (this is mainly a problem of highly reactive polyisobutenes, with their extremely active terminal double bonds) resulting in the formation of halogen-containing by-products which can only be removed with some difficulty, persisting as contaminations. These halogenated by-products dissociate upon exposure to air, releasing hydrogen halides that lead to corrosion of tanks and devices. Besides this, the exo $\mathrm{C}=\mathrm{C}$ bond content decreases during storage. That is assumed to be due to the released hydrogen halides or acidic contaminations which cause isomerization of the terminal double bonds [5]. Additionally, termination of the growing chains with methanol often results in $\mathrm{OH}$-terminated polymers and a further loss of unsaturated end groups [20]. This can only be avoided completely by renunciation of the common methods.

\section{Solvent Stabilized Complexes as New Starting Materials for the Polymerization of Isobutene}

It was found in 1999 that mononuclear acetonitrile ligated transition metal complexes of the general formula $\left[\mathrm{M}(\mathrm{MeCN})_{4}\right]\left[\left(\mathrm{BF}_{4}\right)\right]_{2}\left(\mathrm{M}=\mathrm{Pd}^{\mathrm{II}}\right.$ or first row transition metal ions) can compete well with their dimeric congeners as initiators for the polymerization of cyclopentadiene [21,22]. 
With the exception of $\left[\mathrm{Pd}(\mathrm{MeCN})_{4}\right]\left[\left(\mathrm{BF}_{4}\right)\right]_{2}$, none of these complexes is able to polymerise further monomers. This undergoes a radical change when $\mathrm{BF}_{4}{ }^{-}$is replaced by more weakly coordinating anions like $\mathrm{B}\left(\mathrm{C}_{6} \mathrm{~F}_{5}\right)_{4}{ }_{4}^{-}, \mathrm{B}\left(\mathrm{C}_{6} \mathrm{H}_{3}\left(\mathrm{CF}_{3}\right)_{2}\right)_{4}{ }^{-}$and $\left(\mathrm{C}_{6} \mathrm{~F}_{5}\right)_{3} \mathrm{~B}-\mathrm{C}_{3} \mathrm{H}_{3} \mathrm{~N}_{2}-\mathrm{B}\left(\mathrm{C}_{6} \mathrm{~F}_{5}\right)_{3}{ }^{-}$[23]. This recently described new class of complexes (see Figure 1) enables polymerization of even isobutene [23-28].

Figure 1. General structure of acetonitrile stabilized transition metal complexes with weakly coordinating anions as used for isobutene polymerization.

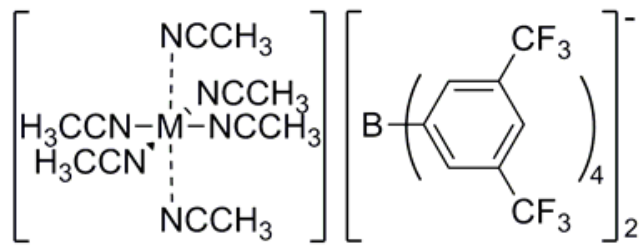

$\left[\mathrm{B}\left(\mathrm{C}_{6} \mathrm{H}_{3}\left(\mathrm{CF}_{3}\right)_{2}\right)_{4}\right]^{-}$

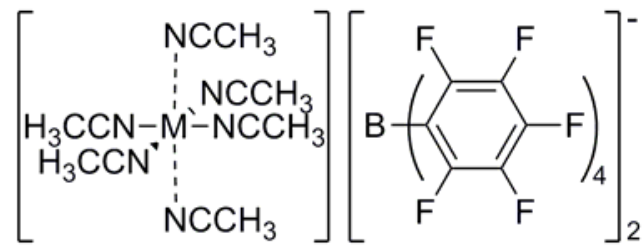

$\left[\mathrm{B}\left(\mathrm{C}_{6} \mathrm{~F}_{5}\right)_{4}\right]^{-}$

$\mathrm{M}=\mathrm{V}^{2+}, \mathrm{Cr}^{2+}, \mathrm{Mn}^{2+}, \mathrm{Fe}^{2+}, \mathrm{Co}^{2+}, \mathrm{Ni}^{2+}, \mathrm{Cu}^{2+} \quad \mathrm{M}=\mathrm{Cr}^{2+}, \mathrm{Fe}^{2+}, \mathrm{Co}^{2+}, \mathrm{Ni}^{2+}, \mathrm{Cu}^{2+}, \mathrm{Zn}^{2+}$

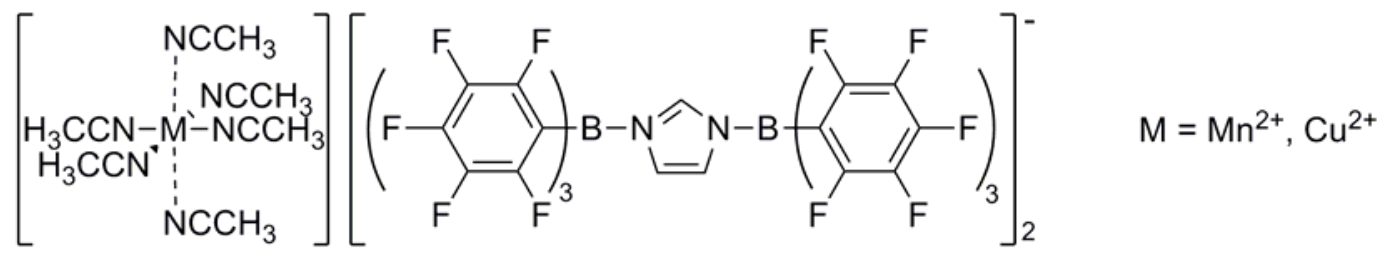

$\left[\left(\mathrm{C}_{6} \mathrm{~F}_{5}\right)_{3} \mathrm{~B}-\mathrm{C}_{3} \mathrm{H}_{3} \mathrm{~N}_{2}-\mathrm{B}\left(\mathrm{C}_{6} \mathrm{~F}_{5}\right)_{3}\right]^{-}$

The great advantage of these complexes is that they can polymerize at room temperature (which was not possible, so far), yielding highly reactive polyisobutenes with adjustable molecular weights between 0.5 and $1.4 \mathrm{~kg} \cdot \mathrm{mol}^{-1}$. Concerning convenient reaction conditions (i.e., use of non-chlorinated solvents, room temperature as reaction temperature) associated with an excellent content of exopositioned terminal double bonds, the best results are reached with $\left[\mathrm{Cu}(\mathrm{MeCN})_{6}\right]\left[\mathrm{B}\left(\mathrm{C}_{6} \mathrm{~F}_{5}\right)_{4}\right]_{2}$ and $\left[\mathrm{Cu}(\mathrm{MeCN})_{6}\right]\left[\mathrm{B}\left(\mathrm{C}_{6} \mathrm{H}_{3}\left(\mathrm{CF}_{3}\right)_{2}\right)_{4}\right]_{2}$ in toluene as solvent (obtained isobutene conversions: 72 to $92 \%$; exo amount of the terminal double bonds: 76 to $85 \%$ at a reaction temperature of $30{ }^{\circ} \mathrm{C}$ ).

By exchanging the ligands from acetonitrile to benzonitrile, the solubility of the complexes in nonpolar, chlorine-free solvents can be enhanced. The complex $\left[\mathrm{Cu}(\mathrm{BnCN})_{6}\right]\left[\mathrm{B}\left(\mathrm{C}_{6} \mathrm{~F}_{5}\right)_{4}\right]_{2}$, for example, reduces the reaction time to $15 \mathrm{~min}\left(\approx 76 \%\right.$ exo double bonds; $73 \%$ conversion in toluene and $30{ }^{\circ} \mathrm{C}$; $\left.\mathrm{c}_{\text {complex }}=0.5 \cdot 10^{-4} \mathrm{~mol} / \mathrm{L}, \mathrm{c}_{\text {isobutene }}=1.78 \mathrm{~mol} / \mathrm{L}\right)[7]$.

Only a small number of acetonitrile ligated molybdenum(III) complexes (see Figure 2) were recently found to be comparably active and soluble in nonpolar solvents [16].

However, a process based on the new class of complexes is less energy consuming and the production of high amounts of chlorine containing waste can be avoided. A further benefit is that until now, no chlorine or hydroxyl (from methanol used for termination) end-groups have ever been observed, using these complexes. For this reason, unlike the polymers obtained with the conventional initiators, each polyisobutene chain contains modifiable unsaturated (end) groups [20,29]. 
Figure 2. General structure of acetonitrile stabilized molybdenum(III) complexes with weakly coordinating anions that were tested for the polymerization of isobutene.
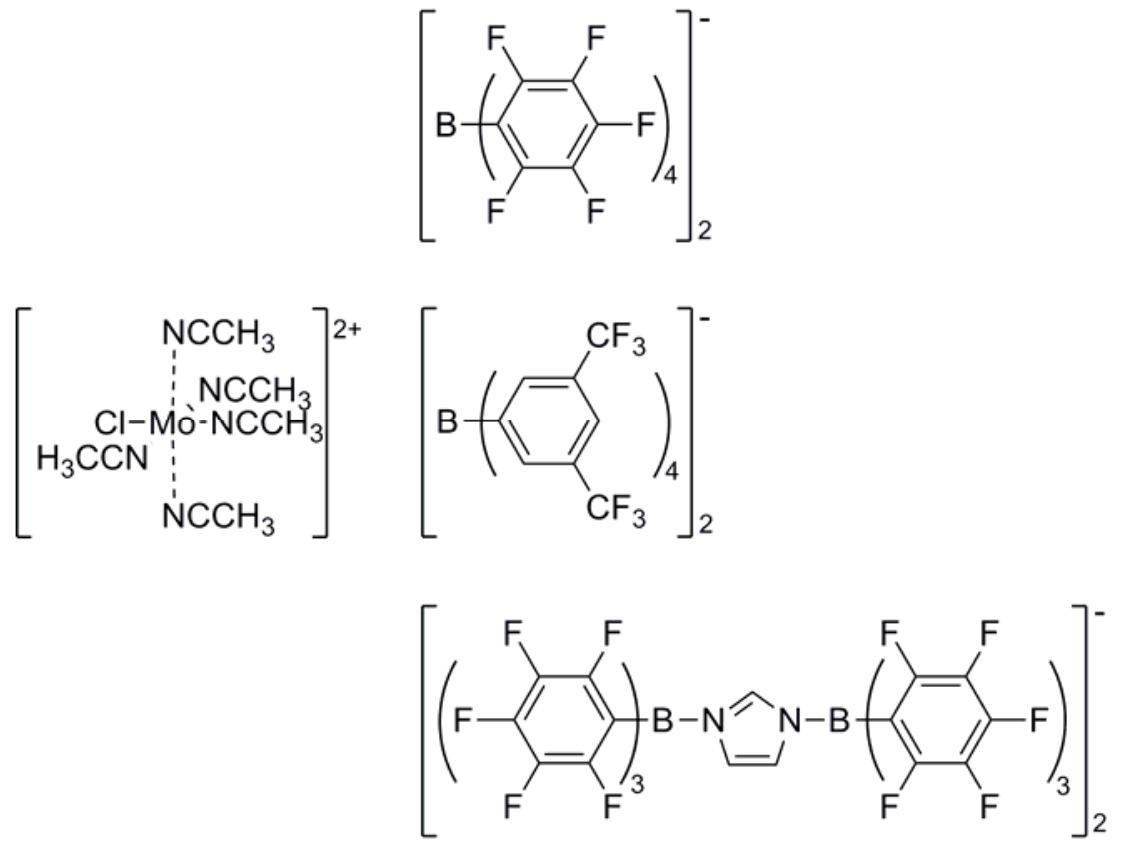

Additional convenience could be provided by immobilization of the most active complexes. Until now, however, no really convincing method (i.e., a method conserving or even improving the yields obtained in homogeneous phase) of immobilization has been presented in the published literature [30].

The most important gain of homogeneous transition metal catalysts is the possibility of controlling the reactivity and selectivity of a reaction under comparatively mild operating conditions. Their handicap is that it is difficult to separate these catalysts from the products to be recycled. Therefore, heterogeneous catalysts are in general regarded as being more desirable for use in industrial processes. Nevertheless, heterogeneous catalysts (often) have severe drawbacks, such as low selectivity, low activity or energy intensive reaction conditions. These drawbacks may be overcome in immobilizing homogeneous catalysts. Up to now the problem of immobilization remains largely unresolved, although some promising attempts have been published. Further work is certainly necessary to bring the catalysts to applicability on larger scale.

\section{Conclusions}

Nitrile stabilized transition metal complexes bearing weakly coordinating counter anions are more efficient and environmentally benign starting materials for the polymerization of isobutylene than the cationic initiators currently applied in industry. Since heterogenization of the complexes would enhance the separability of the complexes and the polymers (metal-free product) and thus opens the possibility of recycling the complexes, additional work has to be done for improving the immobilization of the homo-complexes. Attaining this and other goals may help to design further, even more (energy-) efficient and environmentally benign complexes for the polymerization of isobutene and related industrially relevant reactions. 


\section{Acknowledgements}

We are greatly indebted to the German Research Foundation (DFG), the International Graduate School of Science and Engineering (IGSSE, Ph. D. grant for S. F. R.), the Fonds der Chemischen Industrie and the BASF AG for financial support.

\section{References and Notes}

1. Nuyken, O.; Vierle, M.; Kühn, F.E.; Zhang, Y. Solvent-ligated transition metal complexes as initiators for the polymerization of isobutene. Macromol. Symp. 2006, 236, 69-77.

2. Güterbock, H. Polyisobutylen und Mischpolymerisate; Springer: Berlin, Germany, 1959.

3. Kennedy, J.P.; Maréchal, E. Polyisobutylenes. In Carbocationic Polymerization; John Wiley \& Sons: New York, USA, 1982; pp. 475-488.

4. Rath, H.P.; Mach, H.; Schwahn, H.; Schreyer, P.; Fehr, E.K. (BASF AG). Process for the preparation of polyisobutene succinic anhydrides. EP19940108434, 1994.

5. Rath, H.P.; Perner, T.; Schauss, E. (BASF AG). Herstellung hochreaktiver Polyisobutene mit niedrigem Halogengehalt. DE10361633A1, 2005.

6. Auer, H.; Borchers, D.; Wettling, T. Polyisobutene composition. (BASF AG). Polyisobutene Composition. EP20020782447, 2008.

7. Li, Y.; Voon, L.T.; Yeong, H.Y.; Hijazi, A.K.; Radhakrishnan, N.; Köhler, K.; Voit, B.; Nuyken, O.; Kühn, F.E. Solvent-ligated Copper(II) complexes for the homopolymerization of 2methylpropene. Chem. Eur. J. 2008, 14, 7997-8003.

8. Kresge, E.N.; Schatz, R.H.; Wang, H.C. Isobutylene polymers. In Encyclopedia of polymer science and engineering, $2^{\text {nd }}$ Ed.; Mark, H.F., Bikales, N., Overberger, C.G., Menges, G., Eds.; Wiley: New York, USA, 1987; Vol. 8, pp. 423-448.

9. Immel, W. Polyisobuten. In Ullmanns Encyclopädie der technischen Chemie, $4^{\text {th }}$ Ed.; Ullmann, F., Ed.; Verlag Chemie Weinheim: New York, USA, 1980; Vol. 19, pp. 216-223.

10. Buttlerow, A.; Gorjainow, V. Ber. Dtsch. Chem. Ges. 1873, 6, 561.

11. Lebedew, S.W.; Filonenko, E.P. Untersuchungen auf dem gebiete der polymerisation, X. Mitteilung: Über die einwirkung einiger silicate auf ungesättigte verbindungen. Ber. Dtsch. Chem. Ges. 1925, 58, 163-168.

12. Lebedew, S.W.; Kablianski, G.G. Untersuchungen auf dem Gebiete der Polymerisation, XII. Mitteil.: Über die polymeren Formen des Isobutylens. Ber. Dtsch. Chem. Ges. 1930, 63, 103-112.

13. Otto, M.; Cunradi, M.M. (IG Farbindustrie AG), Polymerizing Isobutylene. DE Patent 641,284, 1937.

14. Kennedy, J.P. Cationic polymerization of olefins: A critical inventory; John Wiley \& Sons: New York, USA, 1975; pp. 10-11.

15. Russel, K.E.; Vail, L.G.M.C. Rates of Initiation of the Cationic Polymerization of Isobutene. In Proceeding of Fourth International Symposium on Cationic Polymerization, University of Akron, Ohio, USA, 1976; Kennedy, J.P., Ed.; John Wiley \& Sons: University of Akron, Ohio, USA, 1976; pp. 183-189. 
16. Hijazi, A.K.; Radhakrishnan, N.; Jain, K.R.; Herdtweck, E.; Nuyken, O.; Walter, H.M.; Hanefeld, P.; Voit, B.; Kühn, F.E., Molybdenum(III) compounds as catalysts for 2-methylpropene polymerization. Angew. Chem. Int. Ed. 2007, 46, 7290-7292.

17. Si, J.; Kennedy, J.P. Analysis of $1 \mathrm{H}-\mathrm{NMR}$ spectra of various end-functionalized polyisobutylenes. J. Polym. Sci. A: Polym. Chem. 1994, 32, 2011-2021.

18. Russel, K.E. The Polymerization of Isobutene by Stannic Chloride, Cationic Polymerisation and Related Complexes. University College of North Staffordshire: North Staffordshire, UK, 1952; Plesch, P.H., Ed.; W. Heffer \& Sons Ltd.: Cambridge, UK, 1952; pp. 114-120.

19. Plesch, P.H. Isobutene. In The Chemistry of Cationic Polymerization; Plesch, P.H., Ed.; Pergamon Press: Oxford, UK, 1963; pp. 142-197.

20. Nuyken, O.; Vierle, M. Polymerization of isobutene: past research and modern trends. Des. Monomers Polym. 2005, 8, 91-105.

21. Kühn, F.E.; Ismeier, J.R.; Schön, D.; Xue, W.M.; Zhang, G.; Nuyken, O. Solvent stabilized transition metal cations as initiators for cyclopentadien polymerization. Macromol. Rapid. Commun. 1999, 20, 555-559.

22. Kühn, F.E.; Schön, D.; Zhang, G.; Nuyken, O. Monometallic solvent stabilized transition metal cations as initiators for cyclopentadiene polymerization. J. Macromol. Sci. Pure Appl. Chem. A 2000, 37, 971-981.

23. Vierle, M.; Zhang, Y.; Herdtweck, E.; Bohnenpoll, M.; Nuyken, O.; Kühn, F.E. Highly reactive polyisobutenes prepared with manganese(II) complexes as initiators. Angew. Chem. Int. Ed. 2003, 42, 1307-1310.

24. Buschmann, W.E.; Miller, J.S. Sources of naked divalent first-row metal ions: Synthesis and characterization of $\left[\mathrm{M}^{\mathrm{II}}(\mathrm{NCMe})_{6}\right]^{2+}(\mathrm{M}=\mathrm{V}, \mathrm{Cr}, \mathrm{Mn}, \mathrm{Fe}, \mathrm{Co}, \mathrm{Ni})$ salts of tetrakis[3,5bis(trifluoromethyl)phenyl]borate. Chem. Eur. J. 1998, 4, 1731-1737.

25. Hijazi, A.K.; Al Hmaideen, A.; Syukri, S.; Radhakrishnan, N.; Herdtweck, E.; Voit, B.; Kühn, F.E. Synthesis and characterization of acetonitrile-ligated transition-metal complexes with tetrakis(pentafluorophenyl)borate as counteranions. Eur. J. Inorg. Chem. 2008, 2008, 2892-2898.

26. Hijazi, A.K.; Yeong, H.Y.; Zhang, Y.; Herdtweck, E.; Nuyken, O.; Kühn, F.E. Isobutene polymerization using $\left[\mathrm{Cu}^{\mathrm{II}}(\mathrm{NCMe})_{6}\right]^{2+}$ with non-coordinating anions as catalysts. Macromol. Rapid Commun. 2007, 28, 670-675.

27. Vierle, M.; Zhang, Y.; Santos, A.M.; Köhler, K.; Haeßner, C.; Herdtweck, E.; Bohnenpoll, M.; Nuyken, O.; Kühn, F.E. Solvent-ligated manganese(II) complexes for the homopolymerization ofIsobutene and the copolymerization of isobutene and isoprene. Chem. Eur. J. 2004, 10, 63236332.

28. Radhakrishnan, N.; Hijazi, A.K.; Komber, H.; Voit, B.; Zschoche, S.; Kühn, F.E.; Nuyken, O.; Walter, M.; Hanefeld, P. Synthesis of highly reactive polyisobutylenes using solvent-ligated manganese(II) complexes as catalysts. J. Polym. Sci. A: Polym. Chem. 2007, 45, 5636-5648.

29. Fleet, M.S.C.; Plesch, P.H. In The Endgroup Problem in Polyisobutene, Cationic Polymerisation and Related Complexes, University College of North Staffordshire, 1952; Plesch, P.H., Ed.; W. Heffer \& Sons Ltd.: Cambridge, UK, 1952; pp. 119-120. 
30. Sakthivel, A.; Hijazi, A.K.; Yeong, H.Y.; Köhler, K.; Nuyken, O.; Kühn, F.E. Heterogenization of a manganese(II) acetonitrile complex on AlMCM-41 and AlMCM-48 molecular sieves by ion exchange. J. Mater. Chem. 2005, 15, 4441-4445.

Sample Availability: Not available.

(C) 2009 by the authors; licensee Molecular Diversity Preservation International, Basel, Switzerland. This article is an open-access article distributed under the terms and conditions of the Creative Commons Attribution license (http://creativecommons.org/licenses/by/3.0/). 